\title{
Primary metabolism in Lactobacillus sakei food isolates by proteomic analysis
}

\author{
Anette McLeod*1,2, Monique Zagorec ${ }^{3}$, Marie-Christine Champomier-Vergès ${ }^{3}$, Kristine Naterstad ${ }^{1}$ and Lars Axelsson'
}

\begin{abstract}
Background: Lactobacillus sakei is an important food-associated lactic acid bacterium commonly used as starter culture for industrial meat fermentation, and with great potential as a biopreservative in meat and fish products. Understanding the metabolic mechanisms underlying the growth performance of a strain to be used for food fermentations is important for obtaining high-quality and safe products. Proteomic analysis was used to study the primary metabolism in ten food isolates after growth on glucose and ribose, the main sugars available for $L$. sakei in meat and fish.
\end{abstract}

Results: Proteins, the expression of which varied depending on the carbon source were identified, such as a ribokinase and a D-ribose pyranase directly involved in ribose catabolism, and enzymes involved in the phosphoketolase and glycolytic pathways. Expression of enzymes involved in pyruvate and glycerol/glycerolipid metabolism were also affected by the change of carbon source. Interestingly, a commercial starter culture and a protective culture strain down-regulated the glycolytic pathway more efficiently than the rest of the strains when grown on ribose. The overall two-dimensional gel electrophoresis (2-DE) protein expression pattern was similar for the different strains, though distinct differences were seen between the two subspecies (sakei and carnosus), and a variation of about $20 \%$ in the number of spots in the 2-DE gels was observed between strains. A strain isolated from fermented fish showed a higher expression of stress related proteins growing on both carbon sources.

Conclusions: It is obvious from the data obtained in this study that the proteomic approach efficiently identifies differentially expressed proteins caused by the change of carbon source. Despite the basic similarity in the strains metabolic routes when they ferment glucose and ribose, there were also interesting differences. From the application point of view, an understanding of regulatory mechanisms, actions of catabolic enzymes and proteins, and preference of carbon source is of great importance.

\section{Background}

Lactobacillus sakei is an important food-associated lactic acid bacterium (LAB). Although initially characterized from rice wine [1] and isolated from plant fermentations $[2,3]$ and fermented fish [4,5], its main habitat is meat [6]. It is widely used as starter culture in the production of fermented meat products [7], and is regarded as a potential meat and fish biopreservative [8-10]. L. sakei resists harsh conditions which often prevail during preservation, such as high salt concentration, low water activity, low temperature and $\mathrm{pH}$ [11]. An important property of the bacterium is the production of lactic acid that acidifies

* Correspondence: anette.mcleod@nofima.no

1 Nofima Mat AS, Norwegian Institute of Food, Fisheries and Aquaculture Research, Osloveien 1, NO-1430 Ås, Norway

Full list of author information is available at the end of the article the product and both inhibits growth of spoilage bacteria and food pathogens, and confers taste and texture to the fermented products. The species has also been observed as a transient inhabitant of the human gastrointestinal tract [12-15]. Sequence analysis of the L. sakei 23K genome has provided valuable information, showing a specialized metabolic repertoire that reflects adaptation to meat products [16].

Among the few sugars available in meat and fish, $L$. sakei utilizes glucose and ribose for growth. The two sugars are fermented through different metabolic pathways: sugar hexose fermentation is homolactic and proceeds via the glycolytic pathway leading to lactate, whereas pentoses are fermented through the heterolactic phosphoketolase pathway ending with lactate and other end products such as acetate $[17,18]$. A correlation between 
glucose and ribose metabolism has been suggested for $L$. sakei, and this metabolism could be advantageous in competition with the other microbial flora found on meat $[17,19]$. With regard to glucose metabolism, the central glycolytic operon, also called the gap operon (cggR-gappgk-tpi-eno), encodes enzymes that catalyse steps of the glycolysis and the putative central glycolytic gene regulator (CggR) [20]. Glucose is transported and phosphorylated by the phosphoenolpyruvate (PEP)-dependent phosphotransferase system (PTS) encoded by the ptsHI operon, and by one or more additional non-PTS permeases [18]. A unique L. sakei rbsUDKR (LSA0200-0203) gene cluster responsible for ribose catabolism has been described, which encodes a ribose transporter (RbsU), a D-ribose pyranase (RbsD), a ribokinase (RbsK) and the ribose operon transcriptional regulator (RbsR) $[16,17,21]$. RbsR was shown to function as a local repressor on rbsUDK, and as a ptsI mutant increased transport and phosphorylation of ribose, the PTS was suggested to negatively control ribose utilization $[16,17,21,22]$. Moreover, regulation by carbon catabolite repression (CCR) mediated by catabolite control protein A (CcpA) has been suggested, as a putative catabolite responsive element (cre) site, the binding site of CcpA, was found preceding $r b s D$ [23-25].

It has been proposed that the species can be divided into two subspecies described as L. sakei subsp. sakei and L. sakei subsp. carnosus based on results from numerical analyses of total cell soluble protein content and randomly amplified polymorphic DNA (RAPD) patterns [2628]. L. sakei species display a large genomic diversity with more than $25 \%$ variation in genome size between isolates [29]. In a previous study, we investigated the diversity of ten $L$. sakei strains by phenotypic and genotypic methods, and could report a wide phenotypic heterogeneity and the presence of two genetic groups which coincide with the subspecies [30]. The growth rates of the strains on glucose and ribose varied, indicating different abilities to metabolize the two sugars. Acidification properties in a meat model also showed differences between the strains, possibly reflecting that some are more suited as starter or protective cultures than others [30]. In this study, we used a proteomic approach to compare the same ten strains, which are isolates from meat and fermented meat products, saké, and fermented fish [30]. We investigated their metabolic routes when growing in a defined medium [31] supplemented with glucose and ribose. Two-dimensional gel electrophoresis (2-DE) combined with mass spectrometry (MS) allowed identification of proteins, the expression of which varied depending on the carbon source used for growth. Previous studies used 2-DE to obtain an overview of global changes in the L. sakei proteome as function of uracil deprivation [32], anaerobiosis [33], adaption to cold temperatures and addition of $\mathrm{NaCl}$
[34], and high hydrostatic pressure [35]. However, studies on the global protein expression patterns during growth of this bacterium on various carbohydrates have not been reported, and importantly, studies to detect specific differences between strains of $L$. sakei are needed. Our aim in this study was to gain further knowledge about the primary metabolism in L. sakei, and to look at strain diversity in this regard.

\section{Methods}

\section{Bacterial strains, media and growth conditions}

The bacterial strains included in this work are listed in Table 1 . The organisms were maintained at $-80^{\circ} \mathrm{C}$ in MRS broth [36] (Oxoid) supplemented with $20 \%$ glycerol. The complex medium MRS (Oxoid) was used for L. sakei propagation, and a completely defined medium (DML) [31], supplemented with either $0.5 \%$ glucose (DMLG), $0.5 \%$ ribose (DMLR) or $0.5 \%$ ribose $+0.02 \%$ glucose (DMLRg), was used for liquid cultures. Optical density at $600 \mathrm{~nm}\left(\mathrm{OD}_{600}\right)$ was monitored on an Ultrospec 3000 UV/Visible Spectrophotometer (Pharmacia Biotech). Cells were grown at $30^{\circ} \mathrm{C}$ in MRS to early exponential phase $\left(\mathrm{OD}_{600}=0.2-0.5\right)$, before inoculation (about $10^{4}$ times diluted) in DML. Under these conditions the cultures were in exponential phase after an overnight incubation. The subcultures were used to inoculate to an initial concentration of $0.07 \mathrm{OD}_{600}$ in fresh DML medium. To monitor the growth rate, flasks containing the cell cultures were stirred moderately to keep bacteria in suspension. For 2-DE analysis samples were prepared from DMLG and DMLRg cultures. Samples were extracted from two independent $100 \mathrm{ml}$ cultures grown to midexponential phase $\left(\mathrm{OD}_{600}=0.5-0.6\right)$.

\section{Extraction of soluble proteins}

Proteins were prepared as described by Marceau et al. [32] with the following modifications: Cultures of $100 \mathrm{ml}$ were centrifuged at $2800 \times g$ at $4^{\circ} \mathrm{C}$ and washed twice in $0.01 \mathrm{M}$ Tris- $\mathrm{HCl}$ buffer, pH 7.5 for $15 \mathrm{~min}$. Bacterial pellets were resuspended in $0.5 \mathrm{ml}$ of the same buffer and $500 \mathrm{mg}$ glass beads were added (acid-washed <106 microns; Sigma-Aldrich). Cells were mechanically disrupted with an FP120 FastPrep cell disruptor (BIO101, Thermo Savant) by four $30 \mathrm{~s}$ cycles of homogenization at speed 6.5 with 1 min intervals in ice. Unbroken cells and large cellular debris were removed by centrifugation at 20 $800 \times g$ for $30 \mathrm{~min}$ at $4^{\circ} \mathrm{C}$. Protein concentrations of the supernatant (cytosolic fraction) were measured using the colorimetric assay $R C D C$ Protein Assay (Bio-Rad), using bovine serum albumin (BSA) as standard protein, according to the manufacturer's instructions. The supernatants were stored in aliquots at $-80^{\circ} \mathrm{C}$. 
Table 1: Strains used in this study.

\begin{tabular}{|c|c|c|}
\hline Bacterial strain & Source & Reference \\
\hline L. sakei $23 \mathrm{~K}$ & Sausage & {$[66,67]$} \\
\hline L. sakei MF1053 & Fermented fish (Norwegian "Rakfisk") & {$[30]$} \\
\hline L. sakei LS 25 & $\begin{array}{l}\text { Commercial starter culture for salami } \\
\text { sausage }\end{array}$ & {$[68]$} \\
\hline L. sakei Lb790x & Meat & [69] \\
\hline L. sakei LTH673 & Fermented sausage & {$[70,71]$} \\
\hline L. sakei MF1328 & Fermented sausage & {$[30]$} \\
\hline L. sakei MF1058 (TH1) & $\begin{array}{l}\text { Vakuum-packed cooked meat, protective } \\
\text { culture }\end{array}$ & {$[9,10]$} \\
\hline L. sakei CCUG 31331a (DSM 15831 b, R 14 b/a) & $\begin{array}{l}\text { Fermented sausage, type strain for } L \text {. sakei } \\
\text { subsp. carnosus }\end{array}$ & {$[27,72]$} \\
\hline L. sakei DSM 20017b (ATCC 15521c) & $\begin{array}{l}\text { Sake, alcoholic beverage made by } \\
\text { fermenting rice, type strain for } L \text {. sakei } \\
\text { subsp. Sakei }\end{array}$ & {$[27]$} \\
\hline L. sakei Lb16 (Lb1048d, CCUG 42687a) & Minced meat & {$[31,73]$} \\
\hline
\end{tabular}

\section{Two-dimensional gel electrophoresis conditions}

Aliquots of the L. sakei cytosolic fraction corresponding to $50 \mu \mathrm{g}$ (analytical gel) or $200 \mu \mathrm{g}$ (preparative gel) of protein were diluted by adding a rehydration buffer (6 M urea (Merck), 2 M thiourea (Merck), 4\% 3- [(3-cholamidopropyl)-dimethylammonio]-1-propanesulfonate (CHAPS; Sigma-Aldrich), 0.5\% immobilized $\mathrm{pH}$ gradient (IPG) buffer pH 4-7 (GE Healthcare Bio-Sciences), and $2.5 \%$ dithiothreitol (DTT; Bio-Rad)) to a final volume of $380 \mu \mathrm{l}$. This solution was used to rehydrate $18-\mathrm{cm} \mathrm{pH} \mathrm{4-7}$ linear IPG strips (GE Healthcare BioSciences). Strips were passively rehydrated at room temperature for 12-16 $h$ under mineral oil, before isoelectric focusing (IEF) was performed in an Ettan IPGphor II unit (GE Healthcare Bio-Sciences, Uppsala, Sweeden) as follows: $200 \mathrm{~V}$ for $1 \mathrm{~h}$, $500 \mathrm{~V}$ for $1 \mathrm{~h}, 1000 \mathrm{~V}$ for $1 \mathrm{~h}$, from 1000 to $8000 \mathrm{~V}$ in 30 $\mathrm{min}$, and finally $8000 \mathrm{~V}$ for $6 \mathrm{~h}$. The strips were incubated at room temperature for $15 \mathrm{~min}$ in equilibration buffer (50 mM Tris- $\mathrm{HCl} \mathrm{pH} 8.8,6 \mathrm{M}$ urea, 30\% (v/l) glycerol (Merck) and 2\% (w/v) sodium dodecyl sulfate (SDS; Shelton Scientific)) supplemented with $1 \%(\mathrm{w} / \mathrm{v})$ DTT, followed by $15 \mathrm{~min}$ in equilibration buffer containing $2.5 \%$ $(\mathrm{w} / \mathrm{v})$ iodoacetamide (Merck). SDS-polyacrylamide gel electrophoresis (SDS-PAGE) using 12.5\% acrylamide gels was carried out with an Ettan DALT II system (GE Healthcare Bio-Sciences, Uppsala, Sweeden). Proteins were resolved at $20^{\circ} \mathrm{C}$ at a current of $2.5 \mathrm{~mA} /$ gel for 45 min and then at $25 \mathrm{~mA} / \mathrm{gel}$ until the tracking dye had migrated to the bottom of the gel. Analytical gels were sil- ver stained as described by Blum et al. [37] and preparative gels according to Shevchenko et al. [38]. For the final analysis, three 2-DE gels were run from each strain from each of the two independent bacterial cultures.

\section{Image and statistical analysis}

Digitized 2-DE images (16-bit greyscale, $300 \mathrm{dpi}$ ) of the stained gels were acquired with an office scanner (Epson Perfection 4990 Photo, Epson) and imported into Progenesis SameSpots software v.3.1 (Nonlinear Dynamics). For each strain, five glucose images and five ribose images were aligned using one selected glucose image as a reference [39]. Spots were detected simultaneously across the images leading to one spot map, an approach which addresses the problems of missing values and reduces variance in spot volume across biological or technical replicates by applying the same spot outline across the image series $[39,40]$. The spot pattern was manually edited, gel artefacts were removed, and images were grouped glucose vs. ribose. An automatic analysis (spot detection, background subtraction, normalisation, and matching) was performed by the software, creating one way ANOVA p-values and q-values as measures of statistical significance, and fold change based on spot normalized volumes of the two groups. Whereas the p-value is a measure of significance in terms of false positive rate, the q-value (or FDR adjusted p-value) is a measure in terms of the false discovery rate (FDR) [41]. Spot normalized volumes were in addition imported into 50-50 MANOVA 
http://www.langsrud.com/stat/ffmanova.htm for statistical analysis. Rotation tests were performed with 9999 simulations for spot normalized volumes, producing qvalues. Differential protein expression was considered to be significant at the level of $\mathrm{q}<0.05$ from both the SameSpots software and rotation tests, and the expression patterns were checked visually to observe how the spot intensity differed. For strain comparison, a representative image from the sequenced strain $L$. sakei $23 \mathrm{~K}$ was used as a reference. Selected images from each of the other strains from both carbon sources were compared to detect distinct strain differences.

\section{Protein identification}

The protein spots of interest presenting a change in volume depending on carbon source used for growth were excised from preparative gels from the sequenced strain 23K. To confirm the identity of the same spots in other strains, we also excised the spots from strains MF1053 and LS 25. Spots presenting distinct strain differences were excised from strain 23K and MF1053. Samples were prepared for matrix-assisted laser desorption/ionizationtime of flight (MALDI-TOF) MS analysis according to the method of Jensen et al. [42] with modifications described previously [43]. For purification of digested proteins columns were prepared by packing a plunge of $\mathrm{C} 18$ material (3 M Empore C18 extraction disc, Varian) into a gel loader tip (20 $\mu$ l, Eppendorf). An Ultraflex MALDI-TOF/ TOF mass spectrometer with the LIFT module (Bruker Daltonics, GmbH, Bremen, Germany) was used for protein identification. Peptide calibration standard I (Bruker Daltonics) was used for external calibration. The software FlexAnalysis 2.4 (Bruker Daltonics) was used to create peak lists using median baseline subtraction with 0.8 in flatness and smoothing by the Savitzky-Golay filter of 0.2 $\mathrm{m} / \mathrm{z}$ in width. BioTools 3.1 (Bruker Daltonics) was used for interpretation of MS and MS/MS spectra. Proteins were identified by peptide mass fingerprinting (PMF) using the database search program MASCOT http:// www.matrixscience.com/, searching against the NCBInr database http://www.ncbi.nih.gov/ with the following settings: Other firmicutes, MS tolerance of $50 \mathrm{ppm}$ and MS/ MS tolerance of $0.5 \mathrm{Da}$, maximum missed cleavage sites was 1 , Carbamidomethyl $(\mathrm{C})$ and Oxidation $(\mathrm{M})$ were set as fixed and variable modification, respectively. The number of peptide matches, sequence coverage, pI and MW were used to evaluate the database search results.

\section{Results and Discussion}

In this study, we used proteomics to compare ten L. sakei food isolates regarding their metabolic routes when growing on glucose and ribose.

\section{Growth of $L$. sakei strains on glucose and ribose}

The ten strains investigated showed faster growth rates when utilizing glucose as the sole carbon source (DMLG; glucose $0.5 \%$ ) compared with ribose (DMLR; ribose $0.5 \%)$, a finding in agreement with previous observations [16-18,30], confirming that glucose is the preferred carbon source in L. sakei. Preliminary 2-DE analysis of strains 23K, MF1053 and LS 25 resulted in gels with large differences in protein spot resolution (results not shown). Gels of samples issued from bacteria grown on ribose as the sole carbon source were of poor quality. Cell proteolysis due to slow growth and prolonged incubation time may result in protein degradation and solubilization defect, as has previously been proposed [44]. Previous studies suggested a regulation of ribose utilization by the PTS and co-metabolism of these two sugars that are present in meat $[17,19,21]$. Since the addition of small amounts of glucose has been described to enhance growth on ribose [45], we used DMLRg (ribose 0.5\%, glucose $0.02 \%$ ) for further experiments. This indeed resulted in faster growth rates and a better spot resolution of the resulting 2-DE gels that were comparable to the gels from bacterial samples grown in DMLG (results not shown). Thus further experiments were performed by growing bacteria in DMLG and DMLRg to study the glucose and ribose metabolisms, respectively.

\section{Protein patterns of the ten $L$. sakei strains}

After growth on glucose (in DMLG) and ribose (in DMLRg) an average of approximately 400 spots was observed after 2-DE in the $\mathrm{pI}$ range investigated. A variation of about $20 \%$ in the number of spots was detected between the strains, as previously observed within the species $[29,35]$. The overall protein expression pattern was similar for the different strains grown on both carbon sources (data not shown), though distinct differences in the $40-\mathrm{kDa}$ region of the 2-DE gels were observed (Figure 1). These differences were identified as resulting from two different migration profiles of four isoforms (different pI) of the glyceraldehyde-3-phosphate dehydrogenase (GapA) protein. The isoforms displayed a size variation, previously described by Chaillou et al. [29] to differentiate two L. sakei subgroups. Grouping of our ten strains based on the GapA isoforms migration profile was identical to the two genetic clusters previously obtained from rapidly amplified polymorphic DNA (RAPD), amplified fragment length polymorphism (AFLP), and microarraybased comparative genome hybridization (CGH) analyses [30]. If those grouping methods reflect the subspecies division of $L$. sakei, eight of our strains including the sequenced strain $23 \mathrm{~K}$ and the type strain CCUG 31331 belong to $L$. sakei subsp. carnosus, while the type strain DSM 20017 and the commercial starter culture strain LS 25 belong to $L$. sakei subsp. sakei. 

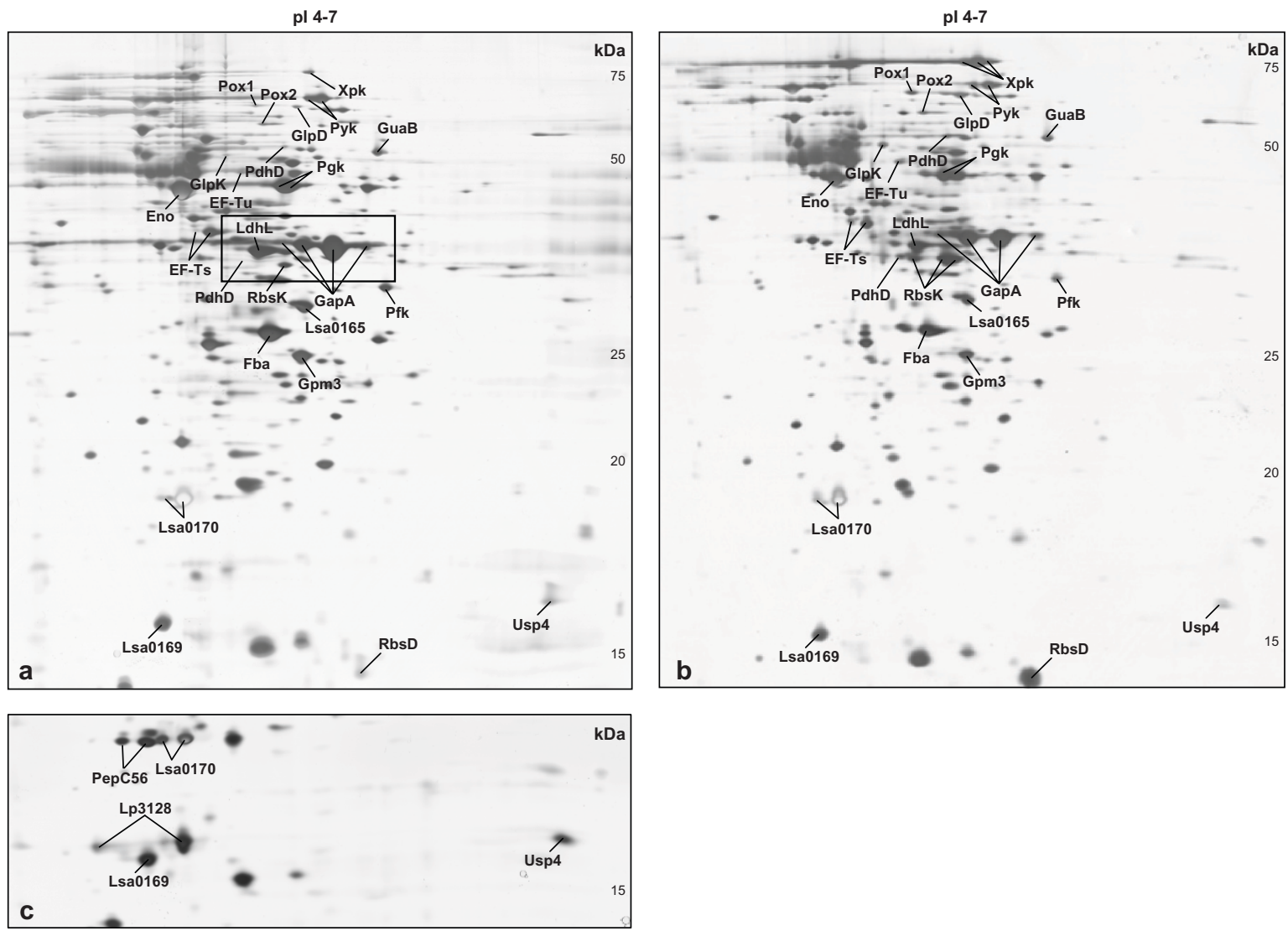

Figure 1 Silver-stained 2-DE gels images of Lactobacillus sakei strain 23K grown in a completely defined medium supplemented with glucose (a) or ribose (b), and the lower part of a 2-DE gel image from L. sakei strain MF1053 grown on glucose (c). Protein ( $50 \mu \mathrm{g})$ was loaded, and 2-DE was performed using a pH range of 4-7 in the first dimension and SDS-PAGE (12.5\%) in the second dimension. Protein size (kDa) is shown on the right side of each gel image. Spots listed in Additional files 1 and 2, Tables S2 and S3 are indicated. The black rectangle (a) shows the region of the GapA isoforms which differ among the strains.

Comparison of protein patterns obtained from cells grown on glucose or ribose revealed, for all the strains, differences in the expression profiles. The spots presenting a volume change depending on the carbon source used for growth and identified by MALDI-TOF MS are shown in Figure 1ab in representative 2-DE gel images. All the proteins could be identified against $L$. sakei $23 \mathrm{~K}$ proteins, as shown in Additional file 1, Table S2. Data obtained for a few spots gave less statistically significant results $(\mathrm{q}=0.05-0.1)$ due to co-migration of proteins which made quantification measurements unreliable. However, visual inspection of these protein spots in the 2 -DE gels confirmed a modification in their volume. Nine proteins displayed a different level of expression in all tested strains, whereas 11 proteins varied in at least one of the strains (Additional file 1). Moreover, when compared to the other strains we observed that $L$. sakei MF1053 over-expressed a set of seven proteins after growth on both carbon sources, as shown in Additional file 2, Table S3. The proteins could be identified against $L$. sakei $23 \mathrm{~K}$ proteins, except for two proteins which identified against proteins from other $L$. sakei strains and were similar to proteins from Lactobacillus plantarum and Lactobacillus buchneri (Additional file 2). The presence of several isoforms with different pIs was also noticed for several proteins (Additional files 1 and 2). Many proteins are modified after synthesis by different types of posttranslational modifications (PTM) which may control the protein activity, and the most common PTM accounted for pI differences is phosphorylation [46].

\section{Proteins differentially expressed between growth on glucose and ribose}

In total, ten proteins were up-regulated in all or most of the strains after growth on ribose. Among those, three are directly involved in ribose catabolism: RbsD, the D- 
ribose pyranase, RbsK, the ribokinase, and Xpk, the putative phosphoketolase. This is in accordance with finding by Stentz et al. [17] who observed the induction of the rbsUDKR operon transcription and an increase of phosphoketolase and ribokinase activity after growth on ribose. The two pyruvate oxidases and two of the four components of the pyruvate dehydrogenase complex (PDC) were also detected as up-regulated in ribose grow cells. In addition, GlpK and GlpD, the glycerol kinase and glycerol-3-phosphate dehydrogenase were detected in higher quantities in most of the strains after growth on ribose. Conversely, six proteins were down-regulated on glucose, of which four were involved in glycolysis. The inosine-5-monophosphate dehydrogenase (GuaB), involved in purine metabolism, and the putative oxidoreductase Lsa0165 were down-regulated, whereas the elongation factor Ts (EF-Ts) was up-regulated on ribose. An overview of the catabolic pathways for glucose (glycolysis) and ribose (phosphoketolase pathway) utilization in L. sakei is shown in Figure 2. Proteins whose expression was modified in cells grown on ribose are shown.

It is likely that the induction of RbsK and Xpk and hence the phosphoketolase pathway in the cells restricts the flow of carbon down the glycolytic route. In many microorganisms, the glycolytic flux depends on the activity of 6-phosphofructokinase (Pfk) and pyruvate kinase (Pyk) $[47,48]$. Similar to several other LAB [48-50] these two enzymes are encoded from a $p f k-p y k$ operon [34], and as reflected at the level of genetic structure, a lower expression of both enzymes was seen on ribose in all strains examined. A lower expression of Pfk was also observed by Stentz et al. [17] during growth on ribose. The glycolytic enzymes fructose-1,6-bisphosphate aldolase (Fba) and a phosphoglycerate mutase (Gpm3) showed a lower expression in most of the strains, and interestingly, strains LS 25 and MF1058 showed a lower expression of three more glycolytic enzymes compared to the rest of the strains. It is possible that these strains have a more efficient mechanism of down-regulating the glycolytic pathway. LS 25 is an industrially used starter culture for fermented sausages, while MF1058 is suitable as a protective culture in vacuum packed fresh meat $[9,10]$. From a meat model system based on minced meat fermentation we previously observed that these two strains performed the fastest acidification of the ten strains, and also had the ability to compete with the indigenous microbiota of the meat batter [30]. Although the triosephosphate isomerase (Tpi), GapA, phosphoglycerate kinase (Pgk), and enolase (Eno) are all encoded from the gap operon [20], our proteome data showed a significantly lower expression only for GapA, Pgk and Eno. In addition, expression of the L-lactate dehydrogenase $(\mathrm{LdhL})$ responsible for the reduction of pyruvate to lactic acid was observed to be lower in the two strains.
The bacterium alters its pyruvate metabolism growing on ribose compared to glucose, possibly since during ribose utilization, more ATP is generated from pyruvate per ribose unit when acetate is produced than when lactate is produced [51]. The up-regulated pyruvate oxidases convert pyruvate into acetyl-phosphate, and the PDC catalyses the transformation of pyruvate to acetyl-CoA (Figure 2).

The increased GlpD enzyme belongs to the glycerol/ glycerolipid catabolic pathway, a pathway linked to membrane properties as glycerol-3-phosphate can be converted to phosphatidic acid, which leads to membrane phospholipid synthesis. Also when exposed to low temperature, this protein shows an increased expression in $L$. sakei [34]. Modified membrane properties could potentially also exist as a response to the higher level of acetate produced when utilizing ribose. Acetate has a higher antimicrobial effect than lactate, with $\mathrm{pK}_{\mathrm{a}}$ values of 4.74 and 3.86, respectively, and the proportion of antimicrobial undissociated acetic acid molecules is increased as the $\mathrm{pH}$ is lowered. The $g l p D$ gene is associated in a $g l p$ operon with glycerol kinase $(g l p K)$, which also showed an increased expression on ribose, and glycerol uptake facilitator protein $(g l p F)$ genes [34].

The role of CcpA in CCR in L. plantarum has previously been established, and CcpA was shown to mediate regulation of the pox genes encoding pyruvate oxidases $[52,53]$. Rud [54] observed an up-regulation of several genes and operons including the pox genes, the $p d h$ operon encoding the PDC, and the $g l p$ operon, during growth on ribose compared with glucose. As putative cre sites [55] were identified in promoter regions, their expression was suggested to be regulated by CcpA-mediated CCR. The putative cre site found preceding $r b s$ in $L$. sakei [25], could indicate that this bacterium possesses global regulation mediated by CcpA. In an $r b s R$ mutant overexpressing RbsUDK, the growth on ribose was not accelerated, whereas in a ptsI mutant, the transcription of rbsUDK was not modified, but transport and phosphorylation of ribose increased. Thus it was concluded that the PTS negatively controls ribose utilization, by a direct or indirect way $[17,22]$. Nevertheless, a change in expression of the PTS enzymes could not be detected in our ribose 2-DE gels. Further experiments are needed to elucidate the mechanism by which the rbs operon is regulated.

The EF-Ts, with an increased expression on ribose, is involved in protein synthesis and translation elongation, and the less expressed GuaB is involved in nucleotide biosynthesis, where ribose is a source for the basic molecule phosphoribosylpyrophosphate (PRPP). Finally, the putative oxidoreductase Lsa0165, also less expressed on ribose, belongs to the short-chain dehydrogenases/ reductases family (SDR), possibly a glucose dehydrogenase. 


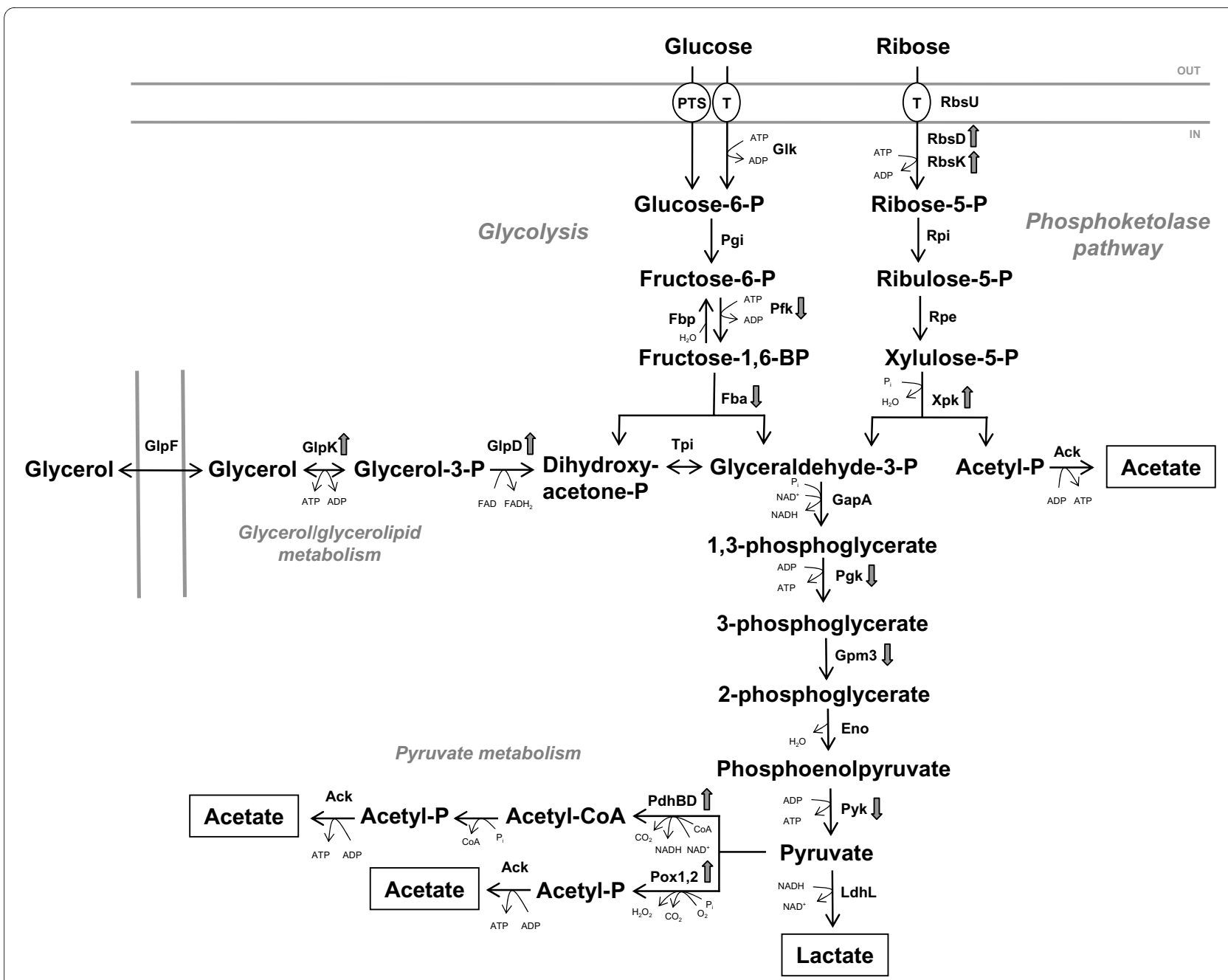

Figure 2 Overview of the metabolic pathways for glucose and ribose fermentation in L. sakei. Enzymes which expression is up- or down-regulated on ribose compared with glucose in the majority of the ten L. sakei strains (see Additional file 1, Table S2) are indicated with upward and downward pointing arrows, respectively. End-products are boxed. PTS, phosphotransferase system; T, transport protein; P, phosphate; B, bis; Glk,

glucokinase; Pgi, phosphoglucoisomerase; Fbp, fructose-1,6-bisphosphatase; Pfk, 6-phosphofructokinase; Fba, fructose-bisphosphate aldolase; RbsU, ribose transporter; RbsD, D-ribose pyranase; RbsK, ribokinase; Rpi, ribose-5-phosphate isomerase; Rpe, ribulose-phosphate 3-epimerase; Xpk, xylulose5-phosphate phosphoketolase; Tpi, triose-phosphate isomerase; GapA, glyceraldehyde-3-phosphate dehydrogenase; Pgk, phosphoglycerate kinase; Gpm3, phosphoglycerate mutase; Eno, enolase; Pyk, pyruvate kinase; LdhL, L-lactate dehydrogenase; PdhBD, pyruvate dehydrogenase complex subunits B and D; Pox1,2, pyruvate oxidase; Ack, acetate kinase; GlpD, glycerol-3-phosphate dehydrogenase; GlpK, glycerol kinase; GlpF, glycerol uptake facilitator protein.

\section{Proteins over-expressed in L. sakei MF1053}

Interestingly, compared to the other strains L. sakei MF1053 showed a higher expression of seven proteins related to stress whatever the carbon source used for growth (Figure 1c). A list of the proteins and references where their involvement in different stresses are described [56-65], are listed in Additional file 2, Table S3. The reason for the observed difference in expression of these stress proteins remains to be elucidated.

\section{Conclusions}

At present, the complete L. sakei genome sequence of strain $23 \mathrm{~K}$ is available [16], and the genome sequence of strain DSM 15831 is currently under assembly http:// www.ncbi.nlm.nih.gov/genomes/lproks.cgi. It is obvious from the data obtained in this study that the proteomic approach efficiently identify differentially expressed proteins caused by the change of carbon source. However, the absence of genome sequence remains a limiting factor for the identification of proteins in the non sequenced strains. Sequence analysis has provided valuable information, showing a metabolic repertoire that reflects adaptation to meat, though genomic analyses provide a static view of an organism, whereas proteomic analysis allows a more dynamic observation. Despite the basic similarity in the strains metabolic routes when they ferment glucose 
and ribose, there were also differences. We are currently combining proteomic and transcriptomic data of different $L$. sakei strains and hope to reveal more about the primary metabolism. From the application point of view, to understand regulatory mechanisms, actions of catabolic enzymes and proteins, and preference of carbon source is of great importance.

\section{Additional material}

\section{Additional file 1 Table S2. Identification of protein spots differentially} expressed depending on the carbon source used for growth in ten $L$. sakei strains. Presents identification and characteristics of protein spots with a significant volume change depending on the carbon source used for growth in ten L. sakei strains.

Additional file 2 Table S3. Proteins over-expressed in L. sakei MF1053.

Presents the identification and characteristics of protein spots overexpressed in L. sakei MF1053 compared to the other L. sakei strains in this study.

\section{Abbreviations}

2-DE: two dimensional gel electrophoresis; MALDI-TOF MS: matrix-assisted laser desorption/ionization-time of flight mass spectrometry; MW: molecular weight; pl: isoelectric point; RbsD: D-ribose pyranase; RbsK: ribokinase; Fbp: fructose-1,6-bisphosphatase; Pfk: 6-phosphofructokinase; Fba: fructose-bisphosphate aldolase; Xpk: xylulose-5-phosphate phosphoketolase; Tpi: triosephosphate isomerase; GapA: glyceraldehyde-3-phosphate dehydrogenase; Pgk: phosphoglycerate kinase; Gpm: phosphoglycerate mutase; Eno: enolase Pyk: pyruvate kinase; LdhL: L-lactate dehydrogenase; PDC: pyruvate dehydrogenase complex; Pox: pyruvate oxidase; Ack: acetate kinase; GlpD: glycerol-3phosphate dehydrogenase; GlpK: glycerol kinase; GuaB: inosine-5-monophosphate dehydrogenase; EFTs: elongation factor Ts; CCR: carbon catabolite repression; CcpA: catabolite control protein $\mathrm{A}$.

\section{Authors' contributions}

AM participated in the design of the study, conducted the experimental work, image and statistical analysis, analyzed and interpreted data, and drafted the manuscript. MZ, MCCV, KN and LA conceived the study, participated in the study design process, and helped write the manuscript. All authors read and approved the final manuscript.

\section{Acknowledgements}

This work was supported by Grant 159058/110 from the Norwegian Research Council and by a Short Term Fellowship from the European Molecular Biology Organization (EMBO). The authors would like to thank Fabienne Baraige and Paricia Anglade for their contribution during the preliminary 2-DE and MS analyses. We also thank Morten Skaugen for excellent technical assistance during MS analysis. Ellen Mosleth Færgestad and Stefania Gudrun Bjarnadottir are acknowledged for their contribution during statistical analysis.

\section{Author Details}

${ }^{1}$ Nofima Mat AS, Norwegian Institute of Food, Fisheries and Aquaculture Research, Osloveien 1, NO-1430 Ås, Norway, 2Department of Chemistry, Biotechnology and Food Science, Norwegian University of Life Sciences, P.O. Box 5003, NO-1432 Ås, Norway and 'Unité Flore Lactique et Environnement Carné, UR309, INRA, Domaine de Vilvert, F-78350 Jouy en Josas, France

Received: 10 February 2010 Accepted: 22 April 2010

Published: 22 April 2010

\section{References}

1. Katagiri H, Kitahara K, Fukami K: The characteristics of the lactic acid bacteria isolated from moto, yeast mashes for sake manufacture. Part IV. Classification of the lactic acid bacteria. Bulletin of Agricultural and Chemical Society of Japan 1934, 10:156-157.

2. Klaenhammer T, Altermann E, Arigoni F, Bolotin A, Breidt F, Broadbent J, Cano R, Chaillou S, Deutscher J, Gasson M, Guchte M van de, Guzzo J,
Hartke A, Hawkins T, Hols P, Hutkins R, Kleerebezem M, Kok J, Kuipers O, Lubbers M, Maguin E, McKay L, Mills D, Nauta A, Overbeek R, Pel H, Pridmore D, Saier M, van Sinderen D, Sorokin A, et al:: Discovering lactic acid bacteria by genomics. Antonie Van Leeuwenhoek 2002, 82:29-58.

3. Vogel RF, Lohmann M, Nguyen M, Weller AN, Hammes WP: Molecular characterization of Lactobacillus curvatus and Lact. sake isolated from sauerkraut and their application in sausage fermentations. J App/ Bacteriol 1993, 74:295-300.

4. Leroi F, Joffraud JJ, Chevalier F, Cardinal M: Study of the microbial ecology of cold-smoked salmon during storage at 8 degrees $C$. Int J Food Microbiol 1998, 39:111-121.

5. Lyhs $U$, Bjorkroth J, Korkeala $\mathrm{H}$ : Characterisation of lactic acid bacteria from spoiled, vacuum-packaged, cold-smoked rainbow trout using ribotyping. Int J Food Microbiol 1999, 52:77-84.

6. Hammes WP, Bantleon A, Min S: Lactic acid bacteria in meat fermentation. FEMS Microbiol Rev 1990, 87:165-174.

7. Hammes WP, Hertel C: New developments in meat starter cultures. Meat Science 1998, 49:125-138.

8. Vermeiren L, Devlieghere F, Debevere J: Evaluation of meat born lactic acid bacteria as protective cultures for biopreservation of cooked meat products. Int J Food Microbiol 2004, 96:149-164.

9. Bredholt S, Nesbakken T, Holck A: Protective cultures inhibit growth of Listeria monocytogenes and Escherichia coli O157:H7 in cooked, sliced, vacuum- and gas-packaged meat. Int J Food Microbiol 1999, 53:43-52.

10. Bredholt S, Nesbakken T, Holck A: Industrial application of an antilisterial strain of Lactobacillus sakei as a protective culture and its effect on the sensory acceptability of cooked, sliced, vacuum-packaged meats. Int J Food Microbiol 2001, 66:191-196.

11. Axelsson L, Ahrné S: Lactic acid bacteria. In Applied microbial systematics Edited by: Priest FG, Goodfellow M. Dordrechet, The Netherlands: Kluwer Academic Press; 2000:365-386.

12. Chiaramonte F, Blugeon S, Chaillou S, Langella P, Zagorec M: Behavior of the meat-borne bacterium Lactobacillus sakei during its transit through the gastrointestinal tracts of axenic and conventional mice. Appl Environ Microbiol 2009, 75:4498-4505.

13. Dal Bello F, Walter J, Hammes WP, Hertel C: Increased complexity of the species composition of lactic acid bacteria in human feces revealed by alternative incubation condition. Microb Ecol 2003, 45:455-463.

14. Heilig HG, Zoetendal EG, Vaughan EE, Marteau P, Akkermans AD, de Vos WM: Molecular diversity of Lactobacillus spp. and other lactic acid bacteria in the human intestine as determined by specific amplification of 16 S ribosomal DNA. Appl Environ Microbio/ 2002, 68:114-123

15. Walter J, Hertel C, Tannock GW, Lis CM, Munro K, Hammes WP: Detection of Lactobacillus, Pediococcus, Leuconostoc, and Weissella species in human feces by using group-specific PCR primers and denaturing gradient gel electrophoresis. App/ Environ Microbiol 2001, 67:2578-2585.

16. Chaillou S, Champomier-Vergès MC, Cornet M, Crutz-Le Coq AM, Dudez AM, Martin V, Beaufils S, Darbon-Rongere E, Bossy R, Loux V, Zagorec M: The complete genome sequence of the meat-borne lactic acid bacterium Lactobacillus sakei 23K. Nat Biotechnol 2005, 23:1527-1533.

17. Stentz R, Cornet M, Chaillou S, Zagorec M: Adaption of Lactobacillus sakei to meat: a new regulatory mechanism of ribose utilization? INRA, EDP Sciences 2001, 81:131-138.

18. Lauret $R$, Morel-Deville F, Berthier F, Champomier Vergès MC, Postma P, Erlich SD, Zagorec M: Carbohydrate utilization in Lactobacillus sake. Appl Environ Microbiol 1996, 62:1922-1927.

19. Champomier-Vergès MC, Chaillou S, Cornet M, Zagorec M: Erratum to " Lactobacillus sakei : recent developments and future prospects". Res Microbiol 2002, 153:115-123.

20. Naterstad K, Rud I, Kvam I, Axelsson L: Characterisation of the gap operon from Lactobacillus plantarum and Lactobacillus sakei. Curr Microbiol 2007, 54:180-185.

21. Stentz R, Zagorec M: Ribose utilization in Lactobacillus sakei : analysis of the regulation of the $r b$ s operon and putative involvement of a new transporter. J Mol Microbiol Biotechnol 1999, 1:165-173.

22. Stentz R, Lauret R, Ehrlich SD, Morel-Deville F, Zagorec M: Molecular cloning and analysis of the ptsHI operon in Lactobacillus sake. Appl Environ Microbiol 1997, 63:2111-2116.

23. Stulke J, Hillen W: Carbon catabolite repression in bacteria. Curr Opin Microbiol 1999, 2:195-201. 
24. Titgemeyer F, Hillen W: Global control of sugar metabolism: a grampositive solution. Antonie Van Leeuwenhoek 2002, 82:59-71.

25. Rodionov DA, Mironov AA, Gelfand MS: Transcriptional regulation of pentose utilisation systems in the Bacillus/Clostridium group of bacteria. FEMS Microbiol Lett 2001, 205:305-314.

26. Klein G, Dicks LMT, Pack A, Hack B, Zimmerman K, Dellaglio F, Reuter G: Emended description of Lactobacillus sake (Katahiri, Katahara and Fukami) and Lactobacillus curvatus (Abo-Elnega Kandler): Numerical classification revealed by protein fingerprinting and identification based on biochemical patterns and DNA-DNA hybridizations. Int J Syst Bacteriol 1996, 46:367-376.

27. Torriani S, Van Reenen GA, Klein G, Reuter G, Dellaglio F, Dicks LM: Lactobacillus curvatus subsp. curvatus subsp. nov. and Lactobacillus curvatus subsp. melibiosus subsp. nov. and Lactobacillus sake subsp. sake subsp. nov. and Lactobacillus sake subsp. carnosus subsp. nov., new subspecies of Lactobacillus curvatus Abo-Elnaga and Kandler 1965 and Lactobacillus sake Katagiri, Kitahara, and Fukami 1934 (Klein et al. emended descriptions), respectively. Int J Syst Bacteriol 1996, 46:1158-1163

28. Berthier F, Ehrlich SD: Genetic diversity within Lactobacillus sakei and Lactobacillus curvatus and design of PCR primers for its detection using randomly amplified polymorphic DNA. Int J Syst Bacteriol 1999, 49:997-1007.

29. Chaillou S, Daty M, Baraige F, Dudez AM, Anglade P, Jones R, Alpert CA, Champomier-Vergès MC, Zagorec M: Intraspecies genomic diversity and natural population structure of the meat-borne lactic acid bacterium Lactobacillus sakei. Appl Environ Microbiol 2009, 75:970-980.

30. McLeod A, Nyquist OL, Snipen L, Naterstad K, Axelsson L: Diversity of Lactobacillus sakei strains investigated by phenotypic and genotypic methods. Syst App/ Microbio/ 2008, 31:393-403.

31. Moretro T, Hagen BF, Axelsson L: A new, completely defined medium for meat lactobacilli. J Appl Microbiol 1998, 85:715-722.

32. Marceau $A$, Mera $T$, Zagorec $M$, Champomier-Vergès MC: Protein expression under uracil privation in Lactobacillus sakei . FEMS Microbiol Lett 2001, 200:49-52.

33. Champomier-Vergès MC, Marceau A, Mera T, Zagorec M: The pepR gene of Lactobacillus sakei is positively regulated by anaerobiosis at the transcriptional level. Appl Environ Microbiol 2002, 68:3873-3877.

34. Marceau A, Zagorec M, Chaillou S, Mera T, Champomier-Vergès MC: Evidence for involvement of at least six proteins in adaptation of Lactobacillus sakei to cold temperatures and addition of $\mathrm{NaCl}$. Appl Environ Microbiol 2004, 70:7260-7268.

35. Jofre A, Champomier-Vergès M, Anglade $P$, Baraige F, Martin B, Garriga M, Zagorec $M$, Aymerich T: Protein synthesis in lactic acid and pathogenic bacteria during recovery from a high pressure treatment. Res Microbiol 2007, 158:512-520.

36. De Man JC, Rogosa M, Shape ME: A medium for the cultivation of lactobacilli. J App/ Microbiol 1960, 23:130-135.

37. Blum $\mathrm{H}$, Beier $\mathrm{H}$, Gross $\mathrm{HJ}$ : Improved silver staining of plant proteins, RNA and DNA in polyacrylamide gels. Electrophoresis 1987, 8:93-99.

38. Shevchenko A, Wilm M, Vorm O, Mann M: Mass spectrometric sequencing of proteins silver-stained polyacrylamide gels. Anal Chem 1996, 68:850-858

39. Faergestad EM, Rye M, Walczak B, Gidskehaug L, Wold JP, Grove H, Jia X, Hollung K, Indahl UG, Westad F, Berg F van den, Martens H: Pixel-based analysis of multiple images for the identification of changes: a novel approach applied to unravel proteome patters of 2-D electrophoresis gel images. Proteomics 2007, 7:3450-3461.

40. Karp NA, Feret R, Rubtsov DV, Lilley KS: Comparison of DIGE and poststained gel electrophoresis with both traditional and SameSpots analysis for quantitative proteomics. Proteomics 2008, 8:948-960.

41. Storey JD, Tibshirani R: Statistical significance for genomewide studies. Proc Natl Acad Sci USA 2003, 100:9440-9445.

42. Jensen ON, Larsen MR, Roepstorff P: Mass spectrometric identification and microcharacterization of proteins from electrophoretic gels: strategies and applications. Proteins 1998, 2:74-89.

43. Jia X, Ekman M, Grove H, Faergestad EM, Aass L, Hildrum Kl, Hollung K: Proteome changes in bovine longissimus thoracis muscle during the early postmortem storage period. J Proteome Res 2007, 6:2720-2731.

44. Rabilloud T: Solubilization of proteins for electrophoretic analyses. Electrophoresis 1996, 17:813-829.
45. Deutscher J, Francke C, Postma PW: How phosphotransferase systemsrelated protein phosphorylation regulates carbohydrate metabolism in bacteria. Microbiology and Molecular Biology Reviews 2006, 70:939-1031.

46. Manning G, Plowman GD, Hunter T, Sudarsanam S: Evolution of protein kinase signaling from yeast to man. Trends Biochem Sci 2002, 27:514-520

47. Kandler O: Carbohydrate metabolism in lactic acid bacteria. Antonie Van Leeuwenhoek 1983, 49:209-224.

48. Branny P, De La Torre F, Garel JR: Cloning, sequencing, and expression in Escherichia coli of the gene coding for phosphofructokinase in Lactobacillus bulgaricus. J Bacteriol 1993, 175:5344-5349.

49. Crispie F, Anba J, Renault P, Ehrlich D, Fitzgerald G, van Sinderen D: Identification of a phosphofructokinase-encoding gene from Streptococcus thermophilus CNRZ1205-a novel link between carbon metabolism and gene regulation? Mol Genet Genomics 2002, 268:500-509.

50. Viana R, Perez-Martinez G, Deutscher J, Monedero V: The glycolytic genes $p f k$ and $p y k$ from Lactobacillus casei are induced by sugars transported by the phosphoenolpyruvate:sugar phosphotransferase system and repressed by CcpA. Arch Microbiol 2005, 183:385-393.

51. Axelsson L: Lactic acid bacteria: classification and physiology. In Lactic acid bacteria: microbiological and functional aspects 3rd edition. Edited by: Salminen S, von Wright A, Ouwehand A. New York, USA: Marcel Dekker, Inc. CRC Press; 2004:1-66.

52. Muscariello L, Marasco R, De Felice M, Sacco M: The functional ccpA gene is required for carbon catabolite repression in Lactobacillus plantarum. Appl Environ Microbiol 2001, 67:2903-2907.

53. Lorquet F, Goffin P, Muscariello L, Baudry JB, Ladero V, Sacco M, Kleerebezem M, Hols P: Characterization and functional analysis of the poxB gene, which encodes pyruvate oxidase in Lactobacillus plantarum. J Bacteriol 2004, 186:3749-3759.

54. Rud I: Primary metabolism in Lactobacillus - a study of control and regulation of acid production. In PhD thesis Ås, Norway: Department of Chemistry, Biotechnology and Food Science, Norwegian University of Life Sciences; 2008.

55. Weickert MJ, Chambliss GH: Site-directed mutagenesis of a catabolite repression operator sequence in Bacillus subtilis. Proc Natl Acad Sci USA 1990, 87:6238-6242.

56. Antelmann H, Bernhardt J, Schmid R, Mach H, Volker U, Hecker M: First steps from a two-dimensional protein index towards a responseregulation map for Bacillus subtilis. Electrophoresis 1997, 18:1451-1463.

57. Duche O, Tremoulet F, Glaser P, Labadie J: Salt stress proteins induced in Listeria monocytogenes. Appl Environ Microbiol 2002, 68:1491-1498.

58. Duche O, Tremoulet F, Namane A, Labadie J: A proteomic analysis of the salt stress response of Listeria monocytogenes. FEMS Microbiol Lett 2002, 215:183-188.

59. Drews $\mathrm{O}$, Weiss W, Reil G, Parlar H, Wait R, Gorg A: High pressure effects stepwise altered protein expression in Lactobacillus sanfranciscensis. Proteomics 2002, 2:765-774.

60. Kleerebezem M, Boekhorst J, van Kranenburg R, Molenaar D, Kuipers OP, Leer R, Tarchini R, Peters SA, Sandbrink HM, Fiers MW, Stiekema W, Lankhorst RM, Bron PA, Hoffer SM, Groot MN, Kerkhoven R, de Vries M, Ursing B, de Vos WM, Siezen RJ: Complete genome sequence of Lactobacillus plantarum WCFS1. Proc Natl Acad Sci USA 2003, 100:1990-1995.

61. Almiron M, Link AJ, Furlong D, Kolter R: A novel DNA-binding protein with regulatory and protective roles in starved Escherichia coli. Genes Dev 1992, 6:2646-2654.

62. Choi SH, Baumler DJ, Kaspar CW: Contribution of $d p$ s to acid stress tolerance and oxidative stress tolerance in Escherichia coli O157:H7. Appl Environ Microbiol 2000, 66:3911-3916.

63. Malone AS, Chung YK, Yousef AE: Genes of Escherichia coli O157:H7 that are involved in high-pressure resistance. Appl Environ Microbiol 2006, 72:2661-2671.

64. Weber A, KogI SA, Jung K: Time-dependent proteome alterations under osmotic stress during aerobic and anaerobic growth in Escherichia coli. J Bacteriol 2006, 188:7165-7175.

65. Hengge R, Bukau B: Proteolysis in prokaryotes: protein quality control and regulatory principles. Mol Microbiol 2003, 49:1451-1462. 
66. Berthier F, Zagorec M, Champomier-Vergès MC, Ehrlich SD, Morel-Deville F: Efficient transformation of Lactobacillus sake by electroporation. Microbiol 1996, 142:1273-1279.

67. Dudez AM, Chaillou S, Hissler L, Stentz R, Champomier-Vergès MC, Alpert CA, Zagorec M: Physical and genetic map of the Lactobacillus sakei $23 \mathrm{~K}$ chromosome. Microbiology 2002, 148:421-431.

68. Hagen $\mathrm{BF}$, Naes $\mathrm{H}$, Holck AL: Meat starters have individual requirements for Mn2+. Meat Science 2000, 55:161-168.

69. Axelsson L, Lindstad G, Naterstad K: Development of an inducible gene expression system for Lactobacillus sakei. Lett Appl Microbiol 2003, 37:115-120.

70. Eijsink VG, Brurberg MB, Middelhoven PH, Nes IF: Induction of bacteriocin production in Lactobacillus sake by a secreted peptide. J Bacterio/ 1996, 178:2232-2237.

71. Tichaczek PS, Vogel RF, Hammes WP: Cloning and sequencing of sakP encoding sakacin $\mathrm{P}$, the bacteriocin produced by Lactobacillus sake LTH 673. Microbiology 1994, 140:361-367.

72. Koort J, Vandamme P, Schillinger U, Holzapfel W, Bjorkroth J: Lactobacillus curvatu s subsp. melibiosus is a later synonym of Lactobacillus sakei subsp. carnosus. Int J Syst Evol Microbiol 2004, 54:1621-1626.

73. Aasen IM, Moretro T, Katla T, Axelsson L, Storro I: Influence of complex nutrients, temperature and $\mathrm{pH}$ on bacteriocin production by Lactobacillus sakei CCUG 42687. Appl Microbiol Biotechnol 2000, 53:159-166

doi: $10.1186 / 1471-2180-10-120$

Cite this article as: McLeod et al., Primary metabolism in Lactobacillus sakei food isolates by proteomic analysis BMC Microbiology 2010, 10:120

Submit your next manuscript to BioMed Central and take full advantage of:

- Convenient online submission

- Thorough peer review

- No space constraints or color figure charges

- Immediate publication on acceptance

- Inclusion in PubMed, CAS, Scopus and Google Scholar

- Research which is freely available for redistribution

Submit your manuscript at www.biomedcentral.com/submit
C Biomed Central 